\title{
Fuel Tax Incidence and Supply Conditions
}

\section{Citation}

Marion, Justin, and Erich Muehlegger. 2010. Fuel Tax Incidence and Supply Conditions. HKS Faculty Research Working Paper Series, RWP10-014, John F. Kennedy School of Government, Harvard University.

\section{Published Version}

http://web.hks.harvard.edu/publications/workingpapers/citation.aspx?Publd=7240

\section{Permanent link}

http://nrs.harvard.edu/urn-3:HUL.InstRepos:4448995

\section{Terms of Use}

This article was downloaded from Harvard University's DASH repository, and is made available under the terms and conditions applicable to Other Posted Material, as set forth at http:// nrs.harvard.edu/urn-3:HUL.InstRepos:dash.current.terms-of-use\#LAA

\section{Share Your Story}

The Harvard community has made this article openly available.

Please share how this access benefits you. Submit a story.

Accessibility 


\section{Fuel Tax Incidence and Supply Conditions Faculty Research Working Paper Series}

\section{Justin Marion}

University of California, Santa Cruz

\section{Erich Muehlegger}

Harvard Kennedy School

\section{April 2010 RWP10-014}

The views expressed in the HKS Faculty Research Working Paper Series are those of the author(s) and do not necessarily reflect those of the John F. Kennedy School of Government or of Harvard University. Faculty Research Working Papers have not undergone formal review and approval. Such papers are included in this series to elicit feedback and to encourage debate on important public policy challenges. Copyright belongs to the author(s). Papers may be downloaded for personal use only. 


\title{
Fuel Tax Incidence and Supply Conditions
}

\author{
Justin Marion ${ }^{\dagger}$ \\ Erich Muehlegger $\ddagger$
}

March 2010

\begin{abstract}
In this paper, we provide new evidence regarding the pass-through of diesel and gasoline taxes to prices, and how the estimated pass-through depends on a variety of supply conditions including a measure of state residual supply elasticity, and refinery and inventory constraints. In addition, we estimate the response of tax incidence to gasoline content regulations, which complicate the supply chain by increasing product heterogeneity. We find that state gasoline and diesel taxes are on average fully passed on to consumers. We also find that the pass-through of diesel taxes is greater in settings where untaxed uses of diesel are more important, which corresponds to times when residual supply is more elastic. We find that only half of the state diesel tax is passed on to consumers when U.S. refinery capacity utilization is above 95 percent. Gasoline taxes, on the other hand, are fully passed through regardless of season or capacity utilization, indicating that a gas tax holiday would provide price relief to consumers. We find that regional gasoline content regulations affect pass-through - we estimate tax pass-through is 22 percentage points lower in a state using two blends of gasoline than a state using one blend of gasoline.
\end{abstract}

\footnotetext{
${ }^{*}$ The authors thank Erzo Luttmer, Raj Chetty, Monica Singhal, and seminar participants at UC Berkeley, Northeastern, UC Santa Cruz, Harvard, Wisconsin, Columbia, the Public Choice Society Annual Conference, and the NBER Economics of Taxation Summer Institute for helpful comments.

${ }^{\dagger}$ University of California, Santa Cruz. marion@ucsc.edu

${ }^{\ddagger}$ John F. Kennedy School of Government, Harvard University. Erich_Muehlegger@ksg.harvard.edu.
} 


\section{Introduction}

Over the past twenty-five years, fuel taxes have represented close to thirty percent of the retail price of diesel and gasoline, on average. The incidence of fuel taxes, and specifically how they respond to market conditions, play a central role in current energy policy debates. Concern over the incidence of taxes was the first argument offered in an open letter signed by 150 prominent economists against the tax moratorium proposed by Sens. Clinton and McCain in Spring 2008. Whether the proposed "gas tax holiday," which would suspend the gasoline tax during the peak driving season, would provide relief to consumers depends crucially on the extent to which lowering taxes reduces the tax-inclusive retail price. Furthermore, recent proposals have suggested that taxing carbon emissions, from both stationary and mobile sources, will play an important part in climate policy. The distributional effects of a carbon-based fuel tax depends to a large extent on the degree to which the taxes are passed onto the consumer.

In addition to the central importance of incidence in current policy debates, the topic of tax incidence is front and center in the textbook treatment of taxation. Despite its central role in public finance, the main predictions of the tax incidence model are largely untested, and there is only sparse evidence regarding the extent to which taxes are incorporated into retail prices, as noted by Poterba (1996) and Doyle and Samphantharak (2008). There is to our knowledge no prior empirical work on the incidence of diesel taxes and sparse empirical work examining the relationship between the incidence of taxes and supply conditions.

We begin by estimating the pass-through rate of gasoline and diesel taxes to retail prices. We then investigate how this pass-through rate depends on several factors that are likely to affect supply elasticity, including refinery capacity utilization, inventory levels, gasoline content regulation, and the utilization of diesel for home heating. Our base findings indicate that diesel taxes are fully passed on to consumers. Increases in state diesel taxes of one cent per gallon lead to an increase in the state retail price of 1.09 cents. Furthermore, the tax is fully realized in the price of diesel in the month of the tax change. This identification strategy will be biased if tax changes are correlated with supply conditions such as capacity utilization. However, we find that these factors are generally unsuccessful at explaining state tax changes. ${ }^{1}$

Consistent with the theory of tax incidence, we find that more of the diesel tax is passed through to consumers when the residual supply of diesel is more elastic. Number 2 distillate can

\footnotetext{
${ }^{1}$ Decker and Wohar (2006) also consider factors shaping state diesel taxes. However they do not examine capacity conditions or neighbor's tax rates, two factors of particular interest to our study. Devereux et al (2007) considers the response of state gasoline taxes to the taxes of other states and the federal government, and Besley and Rosen (1998) consider the tax competition between states and the federal government.
} 
either be sold as diesel fuel or as heating oil. When demand for untaxed uses of diesel are high relative to demand for taxed uses, the residual supply of taxed diesel is more elastic. We find that pass-through is greater during times when heating oil demand is higher, such as in cold months in states where a greater fraction of households use heating oil to heat their homes.

The debate surrounding the gas tax holiday focused in part on whether tax breaks in the summer, when refineries are producing close to capacity and supply may be price inelastic, will result in price relief. Our findings indicate that diesel and gasoline taxes are fully passed through to consumers regardless of season. We also consider refinery capacity utilization specifically. We find that gasoline taxes are also fully passed through regardless of refinery capacity utilization, yet only half of diesel taxes are passed through when capacity utilization exceeds 95 percent.

Fuel storage could also be important for the responsiveness of supply to price. In particular, storage markets may act to arbitrage away intertemporal price differences, which could explain the robustness of the full-pass through rate for gasoline. Greater inventories are associated with greater pass-through of gasoline taxes, though there is some evidence that pass-through for gasoline is lower when supply constraints are likely to bind. Interestingly, diesel taxes are significantly over-shifted to consumers when inventories are unusually low, which suggests that inventories play an important role in helping to mitigate market power.

The final objective of this paper is to examine the relationship between tax incidence and gasoline content regulations designed to reduce automobile air pollution in urban areas. Although little work examines the interaction between regulation and taxes, regulatory-standards and taxes often apply concurrently to industries. Although gasoline content regulations and fuel taxes achieve similar environmental goals by reducing air pollution (directly in the case of content regulations, and indirectly, by increasing gasoline prices), content regulations themselves affect the supply chain by limiting the ability of suppliers to respond to market shocks. We examine within-state changes in the mix of formulations required to serve a state's gasoline demand. We find a relatively large effect - we estimate that tax pass-through in a state like California (that has one uniform, although stringent, blend of gasoline) is approximately 22 percentage points higher than tax pass-through in a state like Illinois (that uses two blends of gasoline in roughly equal proportion).

The empirical literature on the incidence of commodity taxes is fairly sparse. To our knowledge ours is the first study to consider the incidence of diesel fuel taxes. Moreover, our work is unique in its examination of how other regulations affect the incidence of fuel taxes. Chouinard and Perloff $(2004,2007)$, and Alm et al (2009) provide evidence regarding the incidence of gaso- 
line taxes on retail prices using state-level variation in taxes and prices. Chouinard and Perloff (2004) tests the response of incidence to residual supply elasticity at the state level, noting that small states should have a greater supply elasticity and therefore a higher rate of consumer incidence. Doyle and Samphantharak (2008) examine the effects of a gas tax moratorium on prices at the gas station level in Illinois and Indiana. More generally Poterba (1996) examines the incidence of retail sales taxes on clothing prices, Besley and Rosen (1999) consider city-level prices across twelve commodities, and Barnett et al (1995) examines the incidence of cigarette excise taxes.

The paper proceeds as follows. Section 2 presents a theoretical discussion of incidence and supply. Section 3 describes the data and empirical methods we will use. Section 4 presents the empirical results, and Section 5 concludes.

\section{Model}

We consider a quantity tax of $t$ per unit of a good, which is paid by the supplier. A unit mass of firms sell a quantity $q$ of this good to consumers at the tax inclusive price $p$. Consumers have an aggregate demand for the product given by $D(p)$, while supply can be characterized by the function $S(p, t)$. The textbook approach to characterizing incidence starts from the equilibrium, $D(p)=S(p, t)$ and perturbs this equilibrium by changing the tax:

$$
\frac{d p}{d t}=\frac{S_{t}(p, t)}{D_{p}(p)-S_{p}(p, t)}
$$

where $S_{p}, S_{t}$, and $D_{p}$ represent the derivative of supply with respect to price and tax and the derivative of demand with respect to price, respectively.

Suppose diesel is produced at cost $C(q)$ where $C^{\prime}(q)>0$ and $C^{\prime \prime}(q)>0$. If firms behave competitively, this yields the profit function

$$
\Pi(q)=p(q)-t q-C(q)
$$

Firms produce to the point where price is equal to marginal cost, or $q=\phi(p-t)$ where $\phi(p-t)=C^{\prime-1}(p-t)$. Supply is a function of the price net of tax, so that the supply response to taxes is the same as the response to prices: $S_{p}=-S_{t}$. Substituting this into equation (1), multiplying through by $p / q$, and taking the limit as $t \rightarrow 0$, the standard representation of 
incidence is obtained:

$$
\frac{d p}{d t}=\frac{\eta}{\eta-\epsilon}
$$

where $\eta$ and $\epsilon$ are the elasticities of supply and demand, respectively. The rate of pass-through goes up as supply is more elastic and demand is less elastic.

One objective of this paper is to consider factors that shift the elasticity of supply $\eta$ and empirically examine how these shifts affect the pass-through of diesel taxes. Below we describe one way in which we will identify shifts in $\eta$ related to the effect of shifts in demand for fuel oil, which is chemically equivalent to diesel yet is used for a distinct purpose.

\subsection{Residual supply elasticity and fuel oil demand}

In the standard incidence equation derived above, the rate of pass-through depends on the relative elasticities of supply and demand. Characteristics of the market for diesel allow for an investigation into the impact of supply elasticity on the pass-through of diesel taxes. No. 2 distillate can either be sold as diesel or as heating oil, which suggests that the supply of diesel is the residual of No. 2 distillate supply after subtracting the demand for fuel oil. The residual supply of diesel is therefore given by $S^{\text {diesel }}(p)=S(p)-D^{\text {oil }}(p)$, where $S(p)$ is the supply of No. 2 distillate. Differentiating with respect to $p$, we obtain the residual supply elasticity of diesel, ${ }^{2}$

$$
\eta^{\text {diesel }}=\eta / \sigma-\epsilon_{\text {oil }} / \sigma^{o}
$$

where $\eta^{\text {diesel }}$ is the residual supply elasticity of diesel, $\eta$ is the supply elasticity of No. 2 distillate, $\sigma$ is diesel's share of No. 2 distillate, $\epsilon_{\text {oil }}$ is the demand elasticity for fuel oil, and $\sigma^{o}$ is the supply of diesel relative to the supply of fuel oil. The supply elasticity is therefore greater when fuel oil demand is high relative to diesel, and a more elastic supply of diesel should increase the passthrough of the diesel tax to consumers. In the empirical section to follow, we utilize variation in weather and households' use of fuel oil as factors that shift $\sigma$ and $\sigma^{o}$.

\section{$2.2 \quad$ Storage and market power}

Firms' abilities to store gasoline and diesel fuel introduce important complications when considering tax incidence. Storage places restrictions on the intertemporal evolution of prices. Suppose that a change in the tax rate in time $t+1$ is anticipated at time $t$. Allow firms to store an

\footnotetext{
${ }^{2}$ Chouinard and Perloff (2004) perform a similar exercise for gasoline, showing how the residual supply elasticity, and therefore pass-through, in a state is higher as its share of national gasoline demand is lower.
} 
amount of fuel, $S_{t}$, from time $t$ to $t+1$ at a marginal storage cost of $k$. A storage firm chooses storage to maximize expected profits:

$$
E_{t}\left[\Pi_{t+1}\right]=E_{t}\left[p_{t+1}-\tau_{t+1}\right] S_{t} /(1+r)-\left(p_{t}-\tau_{t}\right) S_{t}-k S_{t}
$$

The first-order condition of a competitive storage firm is therefore given by

$$
\left(E\left[p_{t+1}\right]-\tau_{t+1}\right) /(1+r)=p_{t}-\tau_{t}+k .
$$

Thus, a simple model with storage predicts that storage firms will arbitrage away anticipated differences in prices net of taxes. Consequently, if this no-arbitrage condition holds, prices will rise by the amount of the tax increase and taxes will be fully passed onto consumers. Importantly for our context, the condition (6) should hold even when production is temporarily inelastic, such as when refineries face short-run capacity constraints.

There are several reasons why the simple no-arbitrage condition given by equation (6) may not hold for gasoline or diesel fuel. First, although, gasoline and diesel demand are highly seasonal, Borenstein et al (2004) also note apparent capacity constraints in the storage market. If capacity constraints in the storage market are binding, the shadow value of the storage constraint would enter into (6). At the low end, storage obviously cannot fall below zero. More importantly, there may be a nonlinear convenience yield of inventories at the low end. As noted by Pindyck (1994), an important role for inventories is reducing marketing costs, and the cost of drawing down inventories is likely to increase rapidly as inventories go toward zero. For these reasons, as inventories are particularly low or particularly high, the industry supply curve is likely to be more price inelastic.

In addition, storage plays a important role in mitigating market power in wholesale fuel markets. As Borenstein et al (2004) notes, significant barriers to entry exist in the fuel storage market. Consequently, wholesale storage markets tend to be relatively concentrated. Inventories help to mitigate market power concerns that may arise due to short-run mismatches between supply and demand - firms are less able to exercise unilateral market power if other firms hold large inventories. When inventories are low, competitors may be less able to offset a reduction in quantity by a competitor.

A long literature in public finance shows tax pass-through in oligopolistic markets can exceed one. Following the derivation in Stead (1985), a firm with market power facing consumers with constant demand elasticity will more than fully pass taxes along to consumers. For firm i setting 
prices, profit maximizing prices are given by

$$
p=\frac{m c+\tau}{1+\frac{1}{\epsilon_{i}}}
$$

where $\epsilon_{i}$ is the residual demand curve faced by the firm. Since the profit maximizing firm will set price on the elastic portion of the demand curve, a change in $\tau$ increases tax-inclusive prices

by $\frac{1}{1+\frac{1}{\epsilon_{i}}}>1$. If inventories act as a hedge against market power in wholesale fuel markets, the residual demand elasticity faced by the firm would be negatively correlated with competitors' inventories. When inventories are low, firms able to exercise temporary market power may more than fully pass the taxes onto consumers.

Consequently, the relationship between inventories and tax incidence is complicated. In a market with no constraints and costless storage, we should expect to estimate full pass-through in specification in first-differences. If storage capacity constraint bind, pass-through may fall unless low inventories increase firm market power, in which case it is possible that firms more than fully pass taxes along to consumers.

While storage transfers product from one time period to another in response to intertemporal price differences, it is worth noting that cross-state shipments may respond in a similar manner to inter-state differences in net-of-tax prices. With no constraints on shipments, an inter-state no arbitrage condition may hold similar to the expression (6). This is important for interpreting our results, as less-than-full pass-through, for instance, of a state tax change leads to differences across states in the net of tax price. Interstate shipments may therefore lead us to estimate state tax pass-through as 100 percent, regardless of prevailing supply conditions. However, several factors may limit the ability of firms to respond to cross-state differences in prices. First, content regulations may differ across states, preventing the transfer of fuel across borders. Second, supply networks may be sufficiently static to prevent the adjustment to short-run disruptions to supply. We therefore anticipate that a factor affecting a state's short-run supply elasticity, such as the aforementioned extent of fuel oil demand, may alter the pass-through of state taxes to prices.

\subsection{Gasoline Content Regulations}

Finally, environmental regulations that complicate the supply of gasoline may influence passthrough. In 1990, the Clean Air Act Amendment mandated special requirements for fuel in regions failing to meet EPA limits for ozone and carbon monoxide pollution. Many states chose to supplement the federal regulations either by voluntarily adopting the federal requirements or 
by mandating more strict regulations. As a result of federal and state regulation, the number of gasoline blends sold rose from one in 1993 to fifteen in 2001. In addition, in many cases, regulations vary within state, differing in urban and rural areas for example. Muehlegger (2006) studies regional content regulations and finds that specialty blends increased the price of gasoline as well as the price volatility. The introduction of specialty blends complicates the petroleum product supply chain - refiners must determine which blends to produce in advance, pipeline operators must manage the transportation of a larger number of incompatible fuels and wholesale terminal operators may have to manage storage for more than one specification of gasoline at once. Consequently, we anticipate that taxes will be less fully passed-through in states where regulatory heterogeneity is greater.

\section{$3 \quad$ Data and Methods}

\subsection{Data}

We collect a 20-year monthly panel of average state-level prices of gasoline and diesel fuel from the Energy Information Administration (EIA). The EIA reports monthly average price of No. 2 distillate separately by the type of end user for twenty-three states. ${ }^{3}$ To measure the price of No. 2 diesel for on-highway purposes, we use the price to end users through retail outlets. This price is virtually a perfect match of the low-sulfur diesel price, which is almost exclusively for on-highway use in the post-dye period. The EIA publishes average retail gasoline prices for all fifty states monthly from 1983 onwards.

We collect information about the federal and state gasoline and on-road diesel tax rates from 1983 to 2003 from the Federal Highway Administration Annual Highway Statistics. Federal onroad diesel taxes were four cents per gallon in 1981, rising to the current level of 24.4 cents per gallon in 1993. State on-road diesel taxes also rose throughout the period, from a weighted average tax rate of 9.2 cents per gallon in 1981 to 19.4 cents per gallon in $2003{ }^{4}$ Within-state variation also rose throughout the period. In 1981, state on-road diesel taxes varied from a low of 0 cents per gallon in Wyoming to 13.9 cents per gallon in Nebraska. In 2003, Alaska imposes the lowest state diesel taxes, at 8 cents per gallon, while Pennsylvania imposed the highest taxes

\footnotetext{
${ }^{3}$ The EIA surveys prices for states using No. 2 distillate as a "significant heating source." (source: EIA Form 782b explanatory notes) Price data exists for Alaska, Idaho, Illinois, Indiana, Michigan, Minnesota, Ohio, Oregon, Virginia, Washington, West Virginia, Wisconsin and all states in New England (PADD1a) and the Central Atlantic subdistricts (PADD1b).

${ }^{4}$ Oregon does not tax diesel sold for trucking, instead taxing the number of weight-miles driven in the state. For this reason, we exclude Oregon from the subsequent analysis.
} 
of 30.8 cents per gallon. As with diesel taxes, state and federal gasoline taxes increased during this time frame. In 1983, the federal gasoline tax was four cents per gallon and average state gasoline taxes were 11.3 cents per gallon. In 1983, tax rates were lowest in Texas at five cents per gallon and highest in Washington and Minnesota at 16 cents per gallon. By 2003, the federal gasoline tax rose to 18.4 cents per gallon and the average state gasoline tax rose to 20.5 cents per gallon, with a low of 7.5 cents per gallon in Georgia and a high of 30 cents per gallon in Rhode Island.

We also collect data capturing market factors that affect the demand and supply of gasoline and diesel. Our demand shifters for diesel fuel are primarily related to temperature and prevalence of the use of fuel oil as a home heating source. We obtain monthly heating degree days by state from the National Climate Data Center at the National Oceanic and Atmospheric Administration. The number of heating degree days in a month, commonly used to model heating demand, is defined as the sum of the daily number of degrees the temperature is below $65 .{ }^{5}$ We also measure state heating oil prevalence using the fraction of households in a state reporting in the 1990 census to use fuel oil as the primary energy source for home heating. In addition, we collect state unemployment rates and we calculate the minimum diesel and gasoline tax rates in neighboring states.

As one factor affecting the elasticity of fuel supply, we obtain national, monthly refinery capacity utilization from the EIA for 1990 to 2003. Capacity utilization is defined as the ratio of total crude oil input to the total available distillation capacity - capacity utilization captures both production constraints arising from both high demand and from unanticipated refinery repairs. In addition, we obtain monthly data on diesel and gasoline inventories at the PADDlevel from the EIA for our entire time period. We normalize the inventories by the average daily demand in the prior 12 months in each PADD to measure inventories in terms of number of days of supply.

Finally, we collect data on within-state variation in gasoline content regulations. For each state, the EIA tracks the proportion of gasoline meeting federal reformulated gasoline requirements, federal oxygenated gasoline requirements and less stringent conventional gasoline requirements. ${ }^{6}$ To measure within-state heterogeneity, we sum the squared proportions of RFG, oxygenated and conventional gasoline. A value of one denotes uniform regulation for the entire state; a value of one-third denotes that equal amounts of reformulated, oxygenated and

\footnotetext{
${ }^{5}$ For example, if the temperature in a state were 55 degrees for each day in the month of January, the number of heating degree days for each day would be 10 and the number of heating degree days for the month would be 310 .

${ }^{6}$ For additional background on the regulations, see Muehlegger (2006).
} 
conventional gasoline are sold.

Table 1 reports the summary statistics of our variables. To help interpret the results regarding capacity utilization and incidence, the variable means are also reported separately for months with different rates of US refinery capacity utilization. The average tax inclusive retail price is 120.8 cents per gallon over the course of the series. This price is on average highest when capacity utilization is between 90 and 95 percent, though it is in fact lowest at the highest level of capacity utilization. ${ }^{7}$ Over our sample, tax inclusive gasoline prices average 118 cents per gallon. Unlike diesel prices, the average gasoline price rises as refinery capacity utilization increases. The average state diesel tax rate is 18.2 cents per gallon, compared with the average federal tax of 19.8 cents per gallon. Gasoline taxes average 17.1 cents per gallon at the state level and 14.2 cents per gallon at the federal level. The average month has 5.3 heating degree days. Since cold months tend to have lower demand for gasoline, the average degree days are at their highest when refinery capacity utilization is at its lowest. For the average state, 28 percent of households use fuel oil (diesel) to heat their homes, yet this varies considerably across states as standard deviation of this variable is 0.20 .

The average capacity utilization is 91 percent. Low capacity utilization months disproportionately occur in the winter and spring, while 88 percent of high capacity utilization months are in the second and third quarters of the year. Twelve percent of the gasoline sold during the period met federal reformulated gasoline requirements. Approximately two percent of the gasoline sold met federal oxygenated requirements. Content regulations vary substantially both within and across states. Although the mean of the sum of squared content shares is 0.95 , the value is less than 0.75 for approximately ten percent of the sample, and less that 0.6 for approximately five percent of the sample.

Tax increases are most likely to come when capacity utilization is low, as there is a 2.7 percent likelihood a state raises its diesel tax in a month with a capacity utilization of less than 85 percent, compared with 1.6 percent overall. This is primarily due to January being a popular month for tax changes. Yet tax increases when capacity utilization is high is not unlikely. States raise taxes in 1.2 percent of months with a capacity utilization above 95 percent, and tax increases are in fact more likely during these months than when capacity utilization is between 85 and 95 percent.

To further illustrate the variation used in this paper, Figure 1 shows the average diesel tax rate over time for the 22 states we use in the analysis, and the number of states per year

\footnotetext{
${ }^{7}$ Since the capacity utilization series is not available for the entire sample, the means separated by capacity utilization may appear inconsistent with the overall mean.
} 
changing taxes. The average tax per state increases steadily over time, with the growth rate of taxes perhaps slowing somewhat beginning in the nineties. Fewer states changed diesel tax rates during the nineties, yet we still see that several states change taxes in each year of the data. The only exception is 2000 , when tax rates were stable for all states. Figure 2 shows a similar series for gasoline taxes. Gas taxes rise over time, with the rate of growth slowing considerably in recent years. Nonetheless, each year saw at least two states increasing gasoline taxes, with most years witnessing between ten and thirty states changing tax rates.

\subsection{Methods}

The approach taken in this paper is to estimate the effect of federal and state taxes on post-tax (consumer) prices. We assume that the data generating process at the state-month level for prices $p_{i t}$ in cents per gallon is given by:

$$
p_{i t}=\beta_{0}+\beta_{1} T_{i t}^{S}+\beta_{2} T_{t}^{F}+B X_{i t}+\rho_{i}+\sigma_{t}+\epsilon_{i t}
$$

where $T_{i t}^{S}$ and $T_{t}^{F}$ are the state and federal tax rates in cents per gallon, $X_{i t}$ is a vector of timevarying state level covariates, $\rho_{i}$ is a state-level fixed effect meant to capture time-invariant local cost shifters, and $\sigma_{t}$ represents time effects. To estimate (7) in the presence of the unobserved state-level heterogeneity described by $\rho_{i}$, we will estimate the first-differenced equation

$$
\Delta p_{i t}=\beta_{0}+\beta_{1} \Delta T_{i t}^{S}+\beta_{2} \Delta T_{t}^{F}+B \Delta X_{i t}+\sigma_{t}+\epsilon_{i t} .
$$

The coefficients $\beta_{1}$ and $\beta_{2}$ are therefore estimated from contemporaneous changes in taxes and prices.

We perform three sets of analysis. First, we estimate the incidence of state and federal fuel taxes and test whether the tax-inclusive price adjusts immediately to a change in taxes, by including the lagged value of the per unit excise tax. Second, we examine whether the incidence of diesel and gasoline taxes varies with three aspects of supply conditions - changes in the residual supply elasticity arising from changes in the demand for untaxed uses of diesel, supply inelasticity arising from refinery capacity constraints, and supply inelasticity arising from low inventory levels. Finally, we examine the introduction of regional gasoline content regulations and estimate the relationship between regulatory heterogeneity of gasoline content and passthrough of gasoline taxes. 


\section{Results}

\subsection{Basic incidence results}

The results of estimating equation (8) for diesel are presented in Table 2. The specifications presented in column 1 control for year and month effects, while the specification shown in column 2 also includes state-level covariates. By separately controlling for state and month effects, we allow for the identification of the effects of both state and federal fuel taxes. Our findings indicate that a one cent increase in the state tax rate increases the retail price by 1.22 cents, and every one cent increase in federal taxes is estimated increase the consumer price by 1.1 cents. The greater pass-through of state taxes is statistically insignificant, though is consistent with prior estimates from gasoline markets. This is consistent with supply being more responsive to state taxes, perhaps through cross-border shipments, than to federal taxes. Prior theoretical work on incidence suggest that pass-through of greater than 100 percent is possible. (see Katz and Rosen, 1985; Stern 1987, Besley, 1989; Delipalla and Keen, 1992; and Hamilton 1999) While the estimates for the incidence of state taxes suggest more than full pass-through, we cannot reject a null hypothesis of merely full pass-through. It is worth noting that there are few tax changes from which to estimate the pass-through rate of federal taxes. One of these tax changes occurs in October of 1993, coinciding with more stringent content regulations for diesel fuel. In these and future specifications, we will include a separate regressor controlling for the change in prices in October of 1993.

We next account for a richer set of time effects by controlling for year*month effects. Since federal taxes vary only at the year*month level, this precludes the estimation of $\beta_{2}$. Column 3 presents the results. Including the finer time effects has a noticeable effect on the estimates of $\beta_{1}$. We estimate a pass-through rate for state taxes of 1.09 , which as before is not statistically distinguishable from one, but is more precisely estimated.

Changes in taxes are not necessarily immediately reflected in the retail price of diesel. Lags in adjustment by both suppliers and demanders could make short-run elasticities differ from longer-horizon elasticities. To account for the dynamic adjustment of taxes into prices, we follow Alm et al (2009) by including the lagged tax rate in the specification shown in column 4 of Table 2. The coefficient on the interaction term is estimated to be 0.071 and statistically insignificant. Therefore, almost the entire effect of changes in tax rates are immediately realized in prices.

We next investigate whether the price response is symmetric to the sign of the tax change, 
and whether the price response is linear in the size of the tax change. We divide tax changes into 24 evenly sized bins 0.5 cents wide. We then find the average change in price by bin. The results of this exercise are presented in Figure 3. There are few reductions in the diesel tax, so it is difficult to evaluate the symmetry of price changes around a tax change of zero. In general, however, the relationship in the data between price and tax changes appears linear.

One drawback to using state-level price data is that the EIA only reports these data for 23 states. $^{8}$ It is desirable to provide incidence estimates for the entire US, as the states for which we have price data may not be representative. The U.S. is divided into five petroleum districts referred to as PADDs, and the Northeast states are further divided into three sub-PADDS. The EIA reports a complete monthly retail diesel price series for each PADD. We form series of tax rates for the three northeast sub-PADDs and the four PADDs comprising the rest of the U.S. To do so, we take a weighted average of the state tax rates of the states comprising the PADD, weighted by the average monthly consumption of No. 2 distillate consumed by the state. The series of covariates are similarly formed.

Table 3 reports the results of regressing the PADD price on the weighted average PADD tax rate and covariates. In Columns 1 and 2, we include state and month effects separately to allow for the identification of the effect of the federal tax rate. These results indicate somewhat lower pass-through of taxes. In the specification with PADD-level covariates, we estimate the pass-through rate of the average state tax rate of 1.01, while the pass-through rate of the federal tax rate is 0.98 .

In column 3, we display the results of estimating a specification controlling for year*month effects. With the addition of these controls, the estimated pass-through of the average state tax is 1.04, very close to the analogous state-level estimate of 1.09. Finally, we include the lagged value of the state-tax rate, as shown in column 4 . As with the state-level estimates, the effects of prices on taxes seem to be immediately reflected in the retail price of diesel.

In Table 4, we display the basic incidence results for gasoline. These results are not new, as they have been documented using similar variation in Alm et al (2009) and Chouinard and Perloff (2004). Consistent with these papers, we find full pass-through of state taxes. Unlike Chouinard and Perloff, we also find full pass-through of federal gasoline taxes. We employ a specification of the changes of gasoline prices and taxes, a source of difference with Chouinard and Perloff, who estimate a specification in levels. We also find that the gasoline tax is fully incorporated into gasoline prices in the month of the tax change, as the lagged tax rate is

\footnotetext{
${ }^{8}$ This includes Oregon, which we do not include due to a large proportion of its diesel tax revenues derive from a weight-mile tax assessed on diesel trucks.
} 
small and statistically insignificant. These findings are robust to the inclusion of covariates and year*month effects.

We again examine the linearity of the relationship between tax changes and prices by dividing tax changes into 24 evenly spaced bins 0.5 cents wide. The average price change in each of these bins is shown in Figure 4. As with diesel, there are few reductions in state gasoline taxes. However, there appears to be a linear relationship between prices and taxes.

\subsection{Supply Conditions and Tax Incidence}

We next examine whether the incidence of diesel and gasoline taxes varies with three changes in supply conditions - changes in the residual supply elasticity arising the demand for untaxed uses of diesel, supply inelasticity arising from refinery capacity constraints, and supply conditions related to varying inventory levels. To test the first, we will include a triple interaction between the state tax rate, the heating degree days in a state-month, and the prevalence of fuel oil's use to heat homes in the state. In cold weather, demand for untaxed diesel fuel increases with the proportion of households using oil for residential heating. As shown in equation (4), substantial demand for an untaxed alternative will increase the residual supply elasticity of taxed diesel in a state. ${ }^{9}$ While cold weather may directly influence the price due to delivery cost or cold-weather additives, this specification will control for state degree days directly so that the effect of tax changes in cold weather is compared between states with differing levels of household fuel oil use.

The last column of Table 2 presents the relationship between residual supply elasticity of taxed diesel and tax pass-through. To make reading the table easier, degree days have been divided by 100. The coefficient on the interaction between degree days/100, the state tax rate, and the fraction of households using fuel oil to heat their homes is 0.055 . This implies that a state with a one standard deviation greater fraction of households using heating oil (20 percent), in a month with 1000 degree days (approximately equal to February in Chicago), has a pass-through rate 11.0 percentage points higher than a month with zero degree days.

\subsubsection{Capacity Utilization}

To examine how incidence varies with domestic refinery capacity utilization, we separately estimate the incidence of state taxes for months with high and low levels of capacity utilization. If

\footnotetext{
${ }^{9}$ We choose not to use a direct measure of $\sigma_{o}$ for two reasons. First, at least in the pre-dye period, sales of distillate intended for on-highway use comprised a significant share of reported fuel oil sales. Second, the fuel oil series is often missing.
} 
refiners are operating at full capacity, there is little scope to alter production in the short-run in response to changes in taxes. Also, periods of high capacity utilization may indicate particularly strong demand, which could be associated with more inelastic supply. Since supply may only be truly constrained for high levels of capacity utilization, we will allow for the effect to enter nonlinearly. We estimate incidence separately for months with less than 85 percent capacity utilization, between 85 and 90, between 90 and 95, and above 95 percent. Since capacity utilization tends to be higher in the summer months, we also perform the estimation separately for the four quarters of the year to investigate the possibility that the effect depends on the season.

The results for diesel are presented in Table 5. In Panel A, we show the results for capacity utilization. We find that there is virtually no difference in incidence between 80 and 95 percent capacity utilization. The incidence parameter for less than 85 percent capacity utilization is estimated to be 1.29, 1.00 for 85-90 percent capacity utilization, and 1.06 for between 90 and 95 percent capacity utilization. None of these coefficients are statistically distinguishable from one. However, there is a noticeable difference in the estimated incidence for tax changes occurring in months with greater than 95 percent capacity utilization. For these months, only 41 percent of the tax is passed through to consumers. Therefore, we find that the effect of capacity utilization on incidence is highly nonlinear, as it is only noticeable for the most capacity constrained months. However, it is worth noting that even in these extreme situations, almost half of the tax is born by consumers. In Panel B, we present the diesel incidence parameter separately by season. We find that diesel incidence is statistically indistinguishable from one regardless of quarter.

In Table 5 we present similar results for gasoline. Unlike diesel, we find that gasoline incidence is largely independent of capacity utilization. We estimate that consumer incidence is 90 percent of the gasoline tax in the highest capacity utilization months, which is indistinguishable from one. In Panel $\mathrm{B}$, we present results indicating that the pass-through rate of the gas tax is virtually one for the first, second, and third quarters of the year. This suggests that a state tax holiday occurring during the summer would be fully passed to consumers.

\subsubsection{Inventories}

Next, we estimate the association between incidence and inventories, as measured at the PADD level by the days of supply of gasoline and diesel stored at the wholesale level. Inventories are constrained by storage capacity since there are significant barriers to entry in the storage market. Storage is also likely to be constrained at the low end as well due to marketing costs, which are suspected to be highly nonlinear at low levels of inventory (see Pindyck, 1994). Storage 
constraints could indicate a less elastic supply curve, in which case less of the tax is passed on to consumers. On the other hand, stored gallons could represent competition for producers. Low inventory levels could therefore exacerbate any regional market power, and market power could in fact lead to over-shifting of taxes to consumers.

To examine the effect of inventories, we include wholesale inventory levels (measured in terms of days of supply), lagged inventory levels to capture dynamic adjustment, and the interaction between inventory levels and the state tax rate. The former term captures the effect of inventories on price levels, while the interaction term captures the association between inventories and tax incidence. We also consider periods of time where inventories are likely to be constrained, interacting changes in the fuel tax rate with indicators for the monthly inventory lying in the bottom 10 percent and top 10 percent of all monthly inventories in the sample.

In Table 7, we present the results for diesel in panel A and gasoline in panel B. Each specification includes the full set of covariates, as well as month*year fixed effects. We find that, for both gasoline and diesel, the inventories are negatively correlated with the tax-inclusive price. When considering the interaction between inventories and taxes, we find that lower inventory levels are associated with a significant decrease in pass-through for gasoline, but not for diesel. We estimate that a one standard deviation decrease in inventories is associated with approximately 13.1 percentage point greater pass-through of gasoline prices.

Interestingly, pass-through spikes substantially in months where diesel inventories are particularly low. In the bottom ten percent of inventory months, approximately 159 percent of diesel taxes are passed through to consumers. In the absence of market power, pass-through must be between zero and 100 percent regardless of the elasticities of supply and demand. Therefore, rather than indicating a particularly inelastic supply curve during those months, this over-shifting suggests that low inventories are associated with market power on the part of suppliers.

The same does not hold for gasoline. While pass-through is estimated to be higher during the low gasoline inventory months, this effect is not statistically significant. On the other hand, when gasoline inventories are unusually high - in the top ten percent of inventory months pass-through is estimated to be substantially lower. This is consistent with inelastic supply when inventories are constrained. 


\subsubsection{Regional Content Regulations}

Finally, we examine the introduction of regional gasoline content regulations and estimate the relationship between regulatory heterogeneity and pass-through of gasoline taxes. Although the particular example is specific to gasoline, interaction between regulations and taxes is common - many industries face both taxes on inputs or products as well as regulatory standards their processes or products must meet.

We control for changes the composition of gasoline sold within a state by including the percent of gasoline sold within the state meeting federal Reformulated and Oxygenated requirements. ${ }^{10}$ Unfortunately, the EIA withholds content regulation shares in any month that the shares would divulge proprietary information about the sales or operations of a particular firm. After first-differencing, we drop twenty-seven percent of our observations from the base specification. ${ }^{11}$ To test whether heterogeneity in the types of gasoline required in a state constrain suppliers and thereby reduce tax pass-through to consumers, we include two additional terms. As a measure of the homogeneity of regulation within a particular state, we sum the squared market shares of Conventional, Reformulated and Oxygenated gasoline in each state. This approach provides identical intuition to the Hirschman-Herfindahl Index for measuring industry concentration. A value of one denotes a state using only one type of gasoline (regardless of specification), while a value of one-third would denote a state that used all three types of gasoline in equal proportion. The most heterogeneous state in our sample period is Nevada (0.37), which uses roughly equal quantities of all three formulations during the winter. We then interact our measure of regulatory homogeneity with the state's gasoline tax rate to test if incidence is correlated with variation in a state's gasoline regulations.

The estimates are presented in Table 8. All of the specifications include first-differenced control variables as well as month*year fixed effect. Column 1 runs our base gasoline specification that includes (column 3 from Table 4) for the seventy-three percent of the data for which we observe content shares. We estimate a very similar pass-through rate for the subsample - the point estimate is 1.062 (in comparison to a point estimate of 1.053). As with the full sample, we cannot statistically distinguish our estimate from full pass-through. In column 2 , we include the percent of gasoline sold as reformulated and as oxygenated are added as additional covariates to the base specification. While both are positively correlated with price as we expect, neither

\footnotetext{
${ }^{10}$ Diesel must also meet content criteria related to sulfur content. Unfortunately, diesel regulations changed nationally - no local variation exists with which to estimate the effect of diesel content regulations on taxes.

${ }^{11}$ The withheld observations are relatively evenly distributed throughout months of the year and across states. A slightly higher proportion of data is withheld during 1995, the first year of the RFG program. In this year, $38 \%$ of the observations are excluded.
} 
coefficient is statistically significant.

In column 3, we include the sum of squared content shares as well as the interaction term. Consistent with our prediction, we find reduced pass-through of gasoline taxes in states requiring more heterogeneous gasoline supply. We estimate that pass-through is approximately 22 percentage points higher in states with uniform regulations (eg. California or Massachusetts) than a state that uses two gasoline formulations in roughly equal proportion (eg. Illinois). All else equal, shifting from using conventional gasoline to using reformulated gasoline exclusively is associated with a 2.2 cent per gallon increase in the tax inclusive retail price. While the point estimate on the percent of gasoline meeting oxygenated requirements is positive, it is still imprecisely estimated.

\subsection{Drivers of Fuel Tax Changes}

As noted by Doyle and Samphantharak (2008), one concern with regressing price changes on contemporaneous tax changes, as we do in this paper, is the possibility that taxes are set with current demand and supply conditions in mind. If tax changes are more or less likely when prices or capacity utilization are high, then this will tend to bias our estimates of the pass through of diesel taxes.

In this section, we investigate the factors that are correlated with tax changes. We begin by estimating a regression of the change of the state tax rate on a host of covariates, including the federal tax rate, the minimum of the neighboring state's tax rate, recent prices, and current and past capacity utilization. We also consider the effect of these factors on the likelihood that a state raises its tax in a given month.

In Table 9, we present estimates of the determinants of the level of the month-to-month change in the state diesel tax rate. In column 1, we begin by examining the month-to-month changes in the explanatory variables. In general, we have little success in explaining changes in states' tax rates. We see that the change in the federal tax rate and the minimum of the neighbor's tax rate are both negatively correlated with changes in a state's taxes, though neither of these coefficients are statistically significant. Changes in capacity utilization similarly bear little relationship with changes in state tax rates.

Due to policy lags, a contemporaneous correlation is unlikely to exist between explanatory factors and state diesel tax rates. In column 2, we allow for a lagged response to changes in capacity utilization and the minimum of the neighbor's tax. We again see no relationship between lagged capacity utilization and the tax rate, however with this specification, we do 
observe a significant negative relationship between a state's tax rate and the lagged change in the minimum of the neighboring state's tax rate. It is worth noting that this is the only significant coefficient reported in the entire table.

Finally, in column 3 we allow for the state tax rate to depend not on changes in the covariates but instead on their levels. This may be a more sensible model, since the level of capacity utilization, for instance, may be more relevant than its change. Again, however, we see that no covariate is a statistically significant determinant of the change in the state tax rate. These results ameliorate to some degree the concern that important unobserved factors are correlated with both the tax rate and the price.

Specifications involving the change in the tax rate have several disadvantages. In Table 10, we present the results of estimating specifications involving an indicator for whether a state raised its tax rate in a given month as the dependent variable. Whether federal taxes or the minimum tax of neighboring states were raised has no bearing on a state's likelihood of raising the tax in a given period. Similarly, neither current or lagged capacity utilization has an effect on the likelihood of a state raising its taxes. Due to policy lags, the response to actions of other jurisdictions may take time to affect current taxes. We therefore examine tax changes in other jurisdictions occurring within the preceding 12 months. We find that the likelihood a state raises its diesel tax declines both when the federal government has raised its tax in the past 12 months and when the minimum neighboring state's tax rate has increased in the last 12 months.

\section{Conclusion}

In this paper, we examine the effect of diesel and gasoline taxes on retail prices. We find at least full, and potentially more than full, pass-through of both federal and state diesel and gasoline taxes to consumers. The pass-through effects are immediately reflected in prices. For diesel, the pass-through rate is amplified in cold months, particularly in states with a high fraction of households using heating oil. Since heating oil and diesel are chemically equivalent, this is consistent with heating oil use increasing the residual supply elasticity of diesel. We also consider the effect of refinery capacity constraints and wholesale inventory levels on the passthrough of diesel and gasoline taxes. We provide support for the notion that pass-through is considerably less-than 100 percent if tax changes occur when U.S. refinery capacity utilization is high. This holds for diesel taxes but not for gasoline taxes. This could be due to differences in gasoline demand during high capacity utilization months. We find that low inventory levels are associated with higher tax inclusive prices for both gasoline and diesel fuel, and are associated 
with greater tax pass-through for gasoline.

Finally, we examine the interaction between gasoline content regulations and tax incidence. We find a positive and significant relationship between the consistency of a state's gasoline regulations and tax pass-through. We estimate that tax pass-through in a state with consistent regulations (like California) is 22 percentage points higher than pass-through in a state using two blends in equal proportions (like Illinois). This suggests that the interaction between taxes and other forms of regulation is likely to have important implications for tax incidence. 


\section{References}

[1] Alm, James, Edward Sennoga, and Mark Skidmore. (2009) "Perfect competition, urbanicity, and tax incidence in the retail gasoline market," Economic Inquiry 47:1, p.118-134.

[2] Barnett, Paul G., Theodore E. Keeler, and Teh-wei Hu. (1995) "Oligopoly structure and the incidence of cigarette excise taxes," Journal of Public Economics 57:3, p. 457470.

[3] Besley, T. (1989) "Commodity taxation and imperfect competition: A note on the effects of entry," Journal of Public Economics 40, p. 359-367.

[4] Besley, Timothy J. and Harvey S. Rosen. (1998) "Vertical externalities in tax setting: evidence from gasoline and cigarettes," Journal of Public Economics 70, p. 383-398.

[5] - (1999) "Sales taxes and prices: an empirical analysis," National Tax Journal 52, 157178.

[6] Borenstein, Severin, James Bushnell, and Matthew Lewis. (2004) "Market Power in California's Gasoline Market," Center for the Study of Energy Markets working paper 132.

[7] Chouinard, Hayley and Jeffrey M. Perloff. (2004) "Incidence of federal and state gasoline taxes," Economics Letters 83, p. 55-60.

[8] — (2007) "Gasoline Price Differences: Taxes, Pollution, Regulations, Mergers, Market Power, and Market Conditions," The B.E. Journal of Economic Analysis 63 Policy 7:1 (Contributions).

[9] Chernick H. and A. Reschovsky. (1997) "Who pays the gasoline tax?" National Tax Journal $50,157-178$.

[10] Decker, Christopher S. and Mark E. Wohar. (2006) "Determinnats of state diesel fuel excise tax rates: the political economy of fuel taxation in the United States," Annals of Regional Science 41, p. 171-188.

[11] Delipalla, Sofia and Michael Keen. (1992) "The comparison between ad valorem and specific taxation under imperfect competition," Journal of Public Economics 49, p. 351-367.

[12] Devereux, M.P., B. Lockwood, and M. Redoano. (2007) Horizontal and vertical indirect tax competition: Theory and some evidence from the USA," Journal of Public Economics 91, p. 451-479.

[13] Doyle, Joe J. and Krislert Samphantharak. (2008) "\$2.00 Gas! Studying the effects of a gas tax moratorium." Journal of Public Economics 92, p. 869-884.

[14] Hamilton, S.F. (1999) "Tax incidence under oligopoly: a comparison of policy approaches," Journal of Public Economics 71, p. 233245.

[15] Katz, Michael and Harvey S. Rosen. (1985) "Tax analysis in an oligopoly model," Public Finance Quarterly 13, p. 319.

[16] Marion, Justin and Erich Muehlegger. (2008) "Measuring Illegal Activity and the Effects of Regulatory Innovation: Tax Evasion and the Dyeing of Untaxed Diesel," Journal of Political Economy 116:4, p.633-666.

[17] Muehlegger, Erich. (2006) "Gasoline Price Spikes and Regional Gasoline Content Regulations: A Structural Approach." working paper.

[18] Pindyck, Robert S. (1994) "Inventories and the Short-Run Dynamics of Commodity Prices," The Rand Journal of Economics 25:1, pp. 141-159.

[19] Slemrod, Joel and Shlomo Yitzhaki. (2000) "Tax Avoidance, Evasion, and Administration," in A. Auerbach and M Feldstein (eds.), Handbook of Public Economics Volume 3, NorthHolland, p. 1423-1470.

[20] Stern, Nicholas. (1987) "The effects of taxation, price control and government contracts in oligopoly and monopolistic competition," Journal of Public Economics 32, p. 133158. 
Figure 1: Average State Diesel Tax Rates by Year

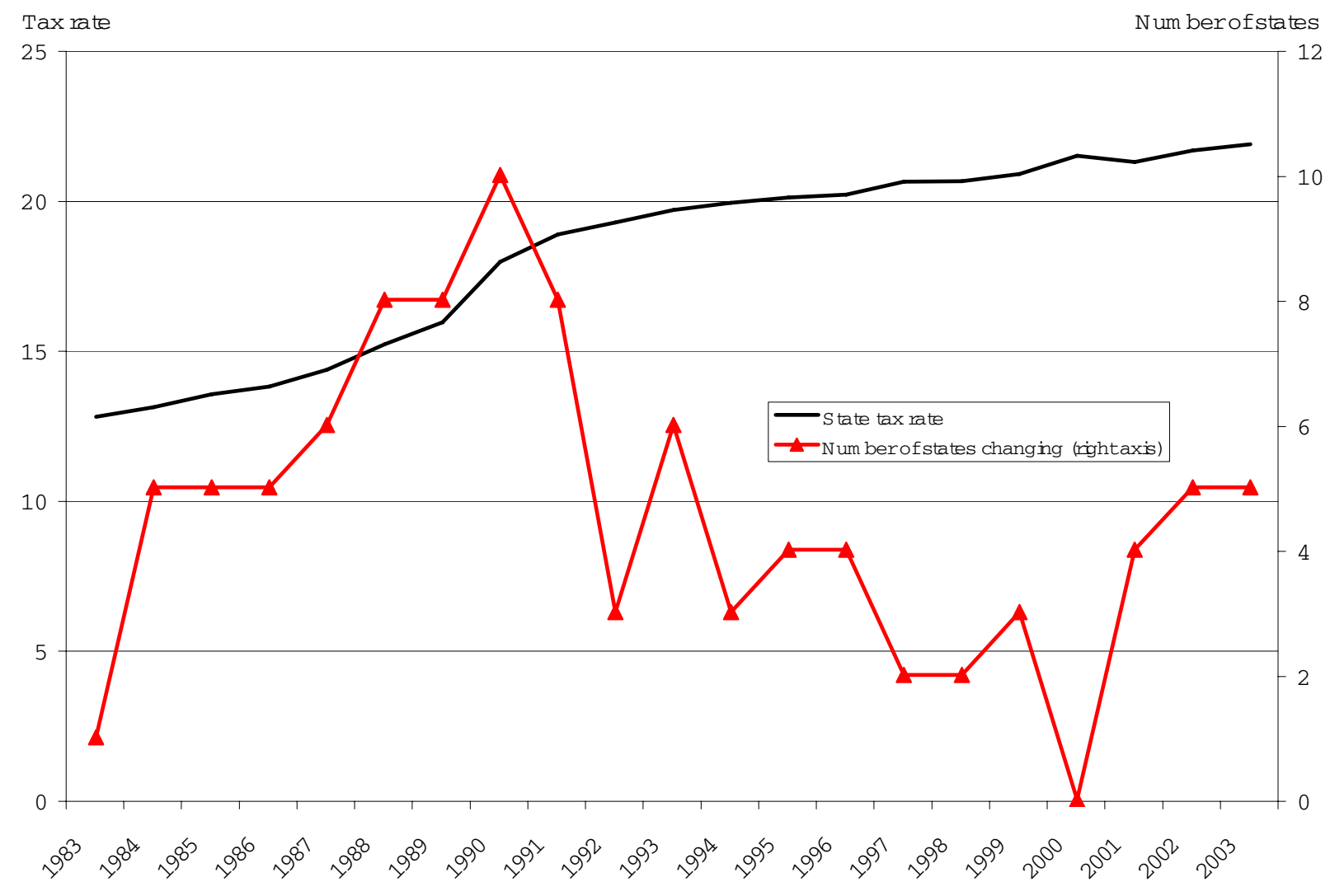


Figure 2: Average State Gasoline Tax Rates by Year

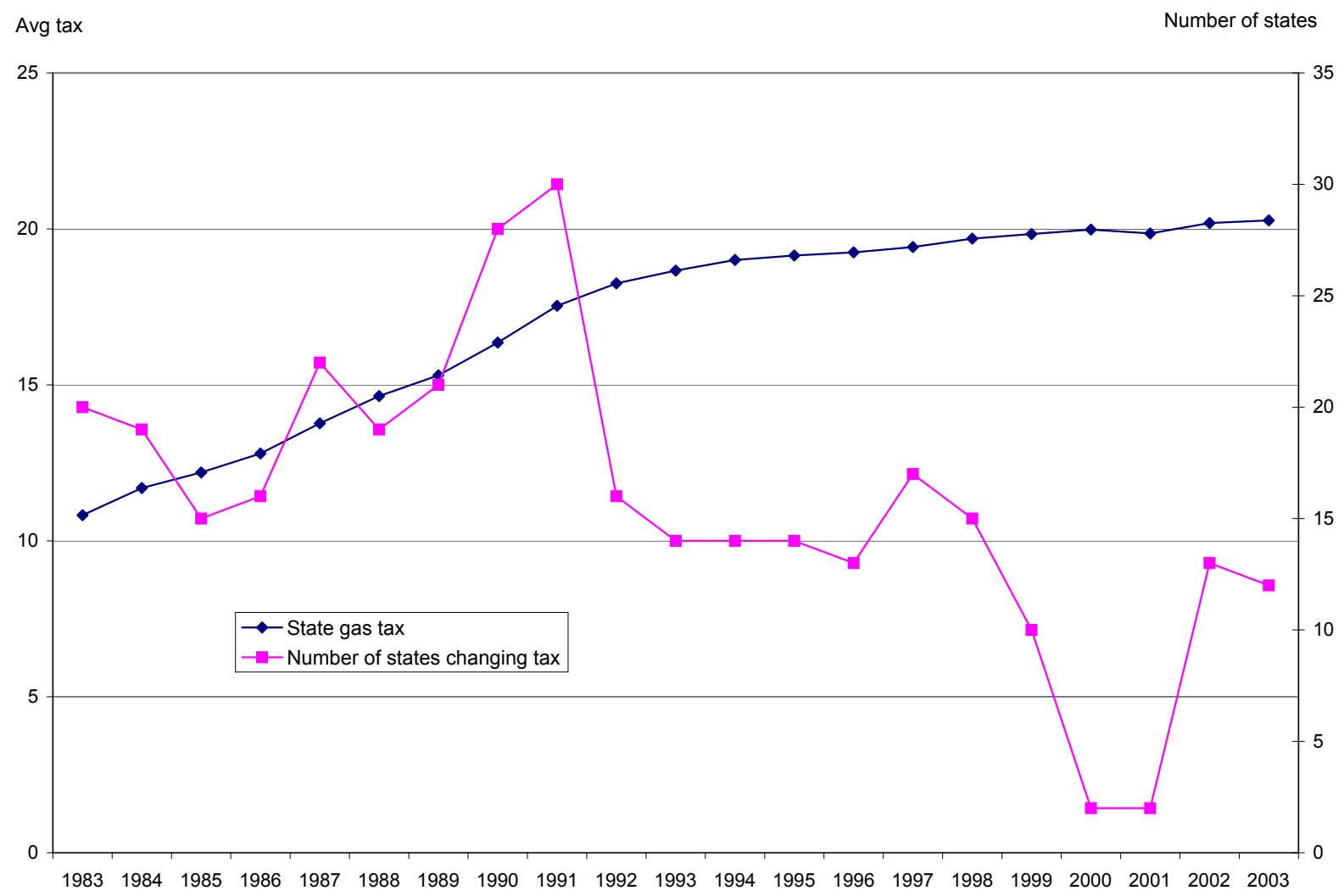


Figure 3: Diesel Price and Tax Changes

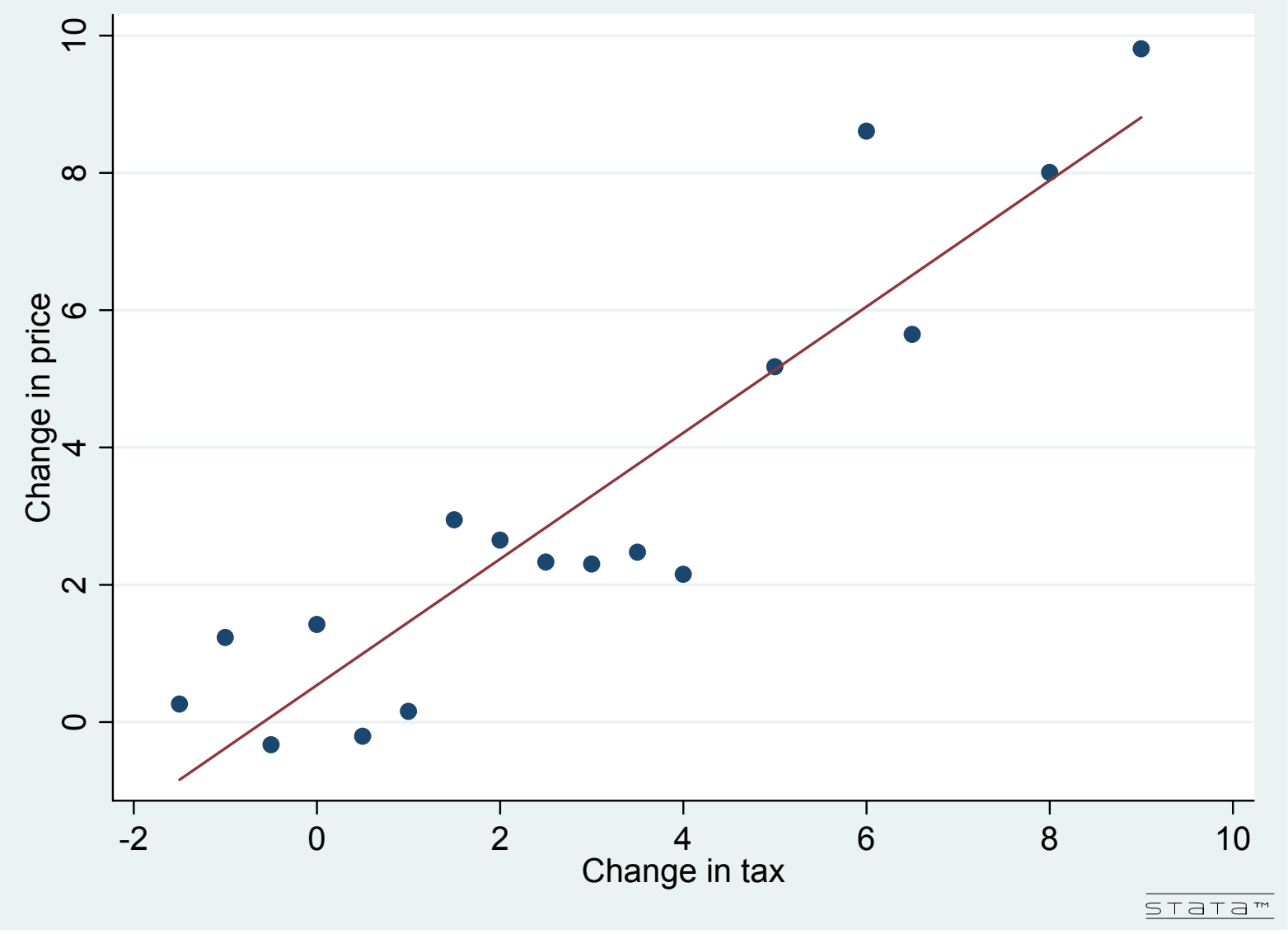


Figure 4: Gasoline Price and Tax Changes

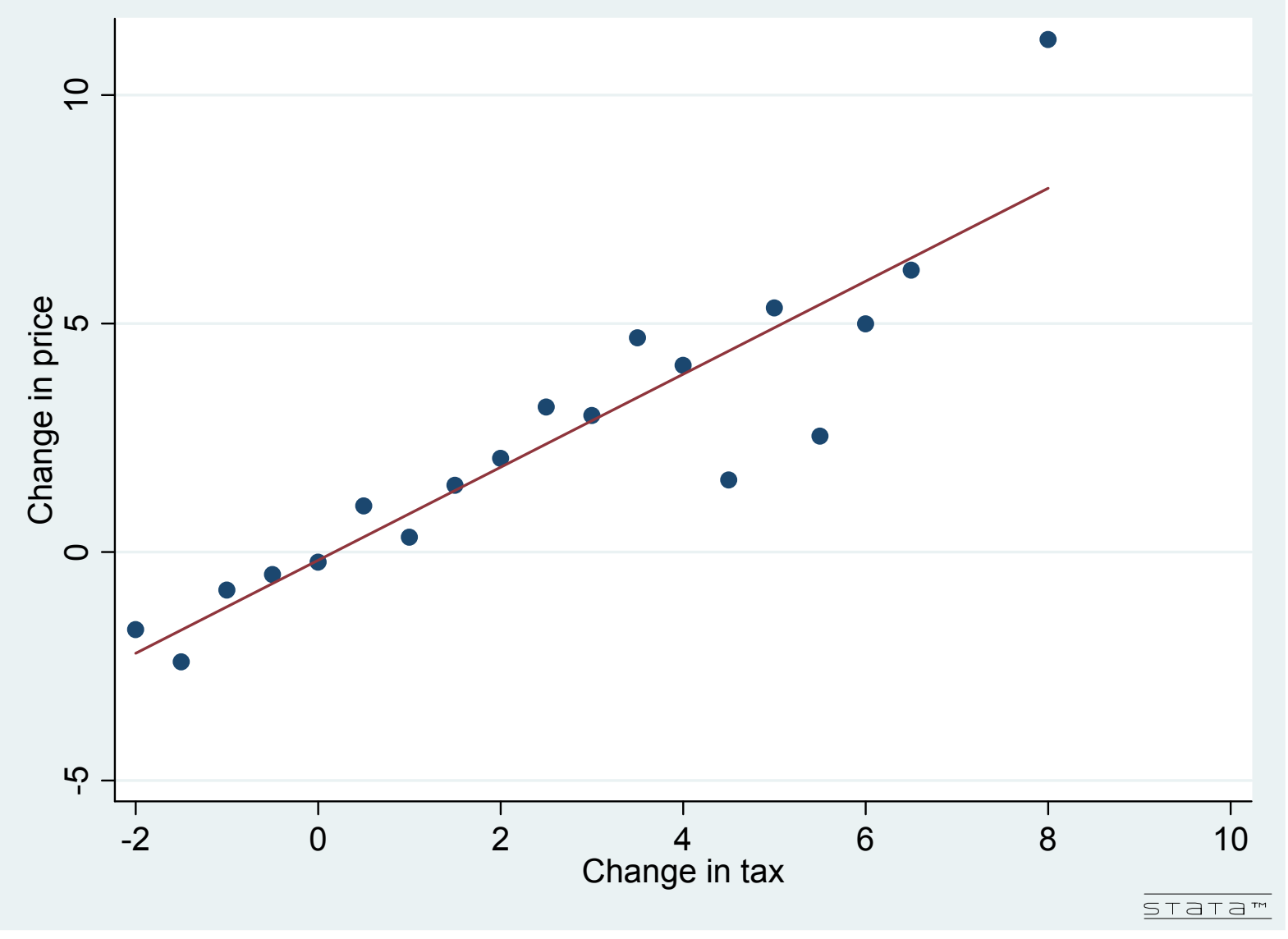


Table 1: Summary Statistics by Capacity Utilization

\begin{tabular}{|c|c|c|c|c|c|}
\hline & $\begin{array}{l}1) \\
\text { Overall } \\
\end{array}$ & $\begin{array}{l}(2) \\
<85 \% \\
\end{array}$ & $\begin{array}{l}3) \\
85-90 \% \\
\end{array}$ & $\begin{array}{l}4) \\
90-95 \% \\
\end{array}$ & $\begin{array}{l}(5) \\
>95 \% \\
\end{array}$ \\
\hline Diesel tax inclusive retail price (c/gall) & $\begin{array}{l}120.83 \\
(19.31)\end{array}$ & $\begin{array}{l}126.21 \\
(15.12)\end{array}$ & $\begin{array}{l}126.15 \\
(20.10)\end{array}$ & $\begin{array}{l}129.43 \\
(18.68)\end{array}$ & $\begin{array}{l}125.76 \\
(18.00)\end{array}$ \\
\hline Gasoline tax inclusive retail price (c/gall) & $\begin{array}{l}118.15 \\
(19.03) \\
\end{array}$ & $\begin{array}{l}105.23 \\
(16.09) \\
\end{array}$ & $\begin{array}{l}112.88 \\
(17.69) \\
\end{array}$ & $\begin{array}{l}125.98 \\
(18.40)\end{array}$ & $\begin{array}{l}119.22 \\
(15.38)\end{array}$ \\
\hline State diesel quantity tax (c/gall) & $\begin{array}{l}18.22 \\
(5.23)\end{array}$ & $\begin{array}{l}19.00 \\
(4.02)\end{array}$ & $\begin{array}{l}20.19 \\
(4.73)\end{array}$ & $\begin{array}{l}20.72 \\
(5.07)\end{array}$ & $\begin{array}{l}20.64 \\
(5.00)\end{array}$ \\
\hline Federal diesel quantity tax (c/gall) & $\begin{array}{l}19.79 \\
(5.24)\end{array}$ & $\begin{array}{l}20.04 \\
(1.91)\end{array}$ & $\begin{array}{l}22.59 \\
(2.12)\end{array}$ & $\begin{array}{l}24.00 \\
(1.22)\end{array}$ & $\begin{array}{l}24.23 \\
(0.77)\end{array}$ \\
\hline State gas quantity tax (c/gall) & $\begin{array}{l}17.08 \\
(5.21)\end{array}$ & $\begin{array}{l}14.25 \\
(3.85)\end{array}$ & $\begin{array}{l}17.14 \\
(4.74)\end{array}$ & $\begin{array}{l}19.38 \\
(4.83)\end{array}$ & $\begin{array}{l}16.13 \\
(5.77)\end{array}$ \\
\hline Federal gas quantity tax (c/gall) & $\begin{array}{l}14.23 \\
(4.41)\end{array}$ & $\begin{array}{l}9.94 \\
(1.93)\end{array}$ & $\begin{array}{l}13.29 \\
(4.07)\end{array}$ & $\begin{array}{l}17.55 \\
(2.29)\end{array}$ & $\begin{array}{l}14.15 \\
(4.96)\end{array}$ \\
\hline Minimum neighboring state diesel tax & $\begin{array}{l}14.27 \\
(4.33)\end{array}$ & $\begin{array}{l}15.22 \\
(3.43)\end{array}$ & $\begin{array}{l}16.03 \\
(3.87)\end{array}$ & $\begin{array}{l}16.39 \\
(4.00)\end{array}$ & $\begin{array}{l}16.37 \\
(4.06)\end{array}$ \\
\hline Minimum neighboring state gas tax & $\begin{array}{l}13.03 \\
(4.51) \\
\end{array}$ & $\begin{array}{l}10.53 \\
(3.08) \\
\end{array}$ & $\begin{array}{l}13.00 \\
(4.21) \\
\end{array}$ & $\begin{array}{l}15.14 \\
(4.30) \\
\end{array}$ & $\begin{array}{l}12.21 \\
(4.79) \\
\end{array}$ \\
\hline Heating degree days & $\begin{array}{l}5.33 \\
(4.49)\end{array}$ & $\begin{array}{l}8.52 \\
(3.21)\end{array}$ & $\begin{array}{l}7.48 \\
(4.32)\end{array}$ & $\begin{array}{l}5.26 \\
(4.26)\end{array}$ & $\begin{array}{l}1.63 \\
(2.30)\end{array}$ \\
\hline Fraction of $\mathrm{HH}$ using heating oil & $\begin{array}{l}0.28 \\
(0.20)\end{array}$ & & & & \\
\hline Diesel Inventories (days) & $\begin{array}{l}51.5 \\
(16.1)\end{array}$ & $\begin{array}{l}54.0 \\
(15.2)\end{array}$ & $\begin{array}{l}49.2 \\
(13.9)\end{array}$ & $\begin{array}{l}48.7 \\
(14.7)\end{array}$ & $\begin{array}{l}48.1 \\
(14.8)\end{array}$ \\
\hline Gasoline Inventories (days) & $\begin{array}{l}38.8 \\
(14.6)\end{array}$ & $\begin{array}{l}43.0 \\
(13.4)\end{array}$ & $\begin{array}{l}39.4 \\
(13.4)\end{array}$ & $\begin{array}{l}34.8 \\
(13.7)\end{array}$ & $\begin{array}{l}34.8 \\
(14.1)\end{array}$ \\
\hline Unemployment rate & $\begin{array}{l}5.71 \\
(2.08)\end{array}$ & $\begin{array}{l}6.73 \\
(1.50)\end{array}$ & $\begin{array}{l}5.89 \\
(1.69)\end{array}$ & $\begin{array}{l}5.06 \\
(1.41)\end{array}$ & $\begin{array}{l}4.73 \\
(1.30)\end{array}$ \\
\hline US Refinery capacity utilization & $\begin{array}{l}91.36 \\
(3.89)\end{array}$ & & & & \\
\hline Percent Reformulated Gasoline & $\begin{array}{l}0.12 \\
(0.29)\end{array}$ & & & & \\
\hline Percent Oxygenated Gasoline & $\begin{array}{l}0.02 \\
(0.10)\end{array}$ & & & & \\
\hline Sum of Squared Content Shares & $\begin{array}{l}0.95 \\
(0.14) \\
\end{array}$ & & & & \\
\hline Diesel tax raised & 0.016 & 0.027 & 0.007 & 0.012 & 0.012 \\
\hline Gas tax raised & 0.022 & 0.027 & 0.032 & 0.014 & 0.010 \\
\hline Quarter 1 & & 0.39 & 0.39 & 0.16 & 0 \\
\hline Quarter 2 & & 0.18 & 0.23 & 0.23 & 0.44 \\
\hline Quarter 3 & & 0.10 & 0.23 & 0.28 & 0.44 \\
\hline Quarter 4 & & 0.33 & 0.15 & 0.34 & 0.11 \\
\hline Number of months & & 51 & 61 & 80 & 36 \\
\hline
\end{tabular}

Standard errors are in parentheses.

Each row reports the mean of the stated variable separately for months with the U.S. refinery capacity utilization stated in the column heading. The exception is the number of months, which simply reports the number of months that experienced the given capacity utilization.

The samples used to compute the means differ between column 1 and columns 2-5. The former uses the entire series, while the latter is based only on those months for which capacity utilization data is available. 
Table 2: Incidence of Diesel Taxes on Prices

\begin{tabular}{|c|c|c|c|c|c|}
\hline & $(1)$ & $(2)$ & $(3)$ & $(4)$ & $(5)$ \\
\hline State diesel tax & $\begin{array}{l}1.262 \\
(0.176)^{* * *}\end{array}$ & $\begin{array}{l}1.218 \\
(0.124) * * *\end{array}$ & $\begin{array}{l}1.087 \\
(0.083)^{* * *}\end{array}$ & $\begin{array}{l}1.087 \\
(0.083) * * *\end{array}$ & $\begin{array}{l}1.071 \\
(0.086)^{* * *}\end{array}$ \\
\hline Federal diesel tax & $\begin{array}{l}1.081 \\
(0.252)^{* * *}\end{array}$ & $\begin{array}{l}1.110 \\
(0.262)^{* * *}\end{array}$ & & & \\
\hline State tax $\mathrm{t}-1$ & & & & $\begin{array}{l}0.071 \\
(0.083)\end{array}$ & \\
\hline State tax $*$ degree days $*$ HH fuel oil frac & & & & & $\begin{array}{l}0.055 \\
(0.022)^{* *}\end{array}$ \\
\hline Diesel tax $*$ degree days & & & & & $\begin{array}{l}0.000 \\
(0.004)\end{array}$ \\
\hline State tax $*$ HH fuel oil frac & & & & & $\begin{array}{l}0.116 \\
(0.513)\end{array}$ \\
\hline WTI Crude Oil Price & $\begin{array}{l}1.285 \\
(0.160)^{* * *}\end{array}$ & $\begin{array}{l}1.232 \\
(0.172)^{* * *}\end{array}$ & & & \\
\hline WTI Price t- 1 & & $\begin{array}{l}0.899 \\
(0.128) * * *\end{array}$ & & & \\
\hline Oct 1993 & $\begin{array}{l}3.673 \\
(1.258)^{* * *}\end{array}$ & $\begin{array}{l}3.613 \\
(1.299) * * *\end{array}$ & & & \\
\hline Minimum neighbor tax & & $\begin{array}{l}1.177 \\
(0.499)^{* *}\end{array}$ & $\begin{array}{l}0.739 \\
(0.456)\end{array}$ & $\begin{array}{l}0.741 \\
(0.456)\end{array}$ & $\begin{array}{l}0.723 \\
(0.438)\end{array}$ \\
\hline Degree days & & $\begin{array}{l}-0.021 \\
(0.120)\end{array}$ & $\begin{array}{l}-0.051 \\
(0.076)\end{array}$ & $\begin{array}{l}-0.050 \\
(0.078)\end{array}$ & $\begin{array}{l}0.226 \\
(0.130) *\end{array}$ \\
\hline Degree days $*$ HH Oil Frac. & & $\begin{array}{l}0.507 \\
(0.151) * * *\end{array}$ & $\begin{array}{l}0.512 \\
(0.135)^{* * *}\end{array}$ & $\begin{array}{l}0.506 \\
(0.138) * * *\end{array}$ & $\begin{array}{c}-0.502 \\
(0.386)\end{array}$ \\
\hline Unemployment rate & & $\begin{array}{l}0.481 \\
(0.822)\end{array}$ & $\begin{array}{l}0.446 \\
(0.498)\end{array}$ & $\begin{array}{l}0.339 \\
(0.506)\end{array}$ & $\begin{array}{l}0.424 \\
(0.495)\end{array}$ \\
\hline Year, month effects & $\mathrm{X}$ & $\mathrm{X}$ & & & \\
\hline $\begin{array}{l}\text { Year*month effects } \\
\text { Observations }\end{array}$ & & & & & $\begin{array}{l}\mathrm{X} \\
5200\end{array}$ \\
\hline $\begin{array}{l}\text { Observations } \\
\text { R-squared }\end{array}$ & $\begin{array}{l}5272 \\
0.46\end{array}$ & 5133 & $\begin{array}{l}5200 \\
0.77\end{array}$ & $\begin{array}{l}5133 \\
077\end{array}$ & $\begin{array}{l}5200 \\
0.77\end{array}$ \\
\hline
\end{tabular}

Standard errors clustered by year*month are in parentheses.

$*, * *, * * *$ denote significance at the $90 \%, 95 \%$, and $99 \%$ level, respectively.

The dependent variable is the one month change in the tax inclusive retail price of No. 2 diesel. Each independent variable has been first-differenced. 
Table 3: Incidence of Diesel Taxes on Prices, PADD level

$(1)$

State diesel tax
Federal diesel tax
State tax t -1
Covariates
Year, month effects
Year*month effects
Observations
R-squared

$(2)$

$\begin{array}{ll}0.960 & 1.009 \\ (0.169)^{* * *} & (0.175) * * * \\ 0.979 & 0.983 \\ (0.178)^{* * *} & (0.178)^{* * *}\end{array}$

(3)

(4)

$\begin{array}{ll}1.037 & 1.051 \\ (0.133)^{* * *} & (0.158)^{* * *} \\ & \\ & 0.032 \\ & (0.187) \\ \mathrm{X} & \mathrm{X} \\ \mathrm{X} & \mathrm{X} \\ 1706 & 1698 \\ 0.85 & 0.85\end{array}$

Standard errors clustered by year*month are in parentheses.

$*, * *, * * *$ denote significance at the $90 \%, 95 \%$, and $99 \%$ level, respectively.

The dependent variable is the one month change in the PADD-level tax inclusive price. The PADD level tax rate is obtained by taking a weighted average of the tax rates across states within the PADD. The weights used are the average monthly quantity of No. 2 distillate consumed in the state.

Other controls in the specification shown in column 2 include WTI Crude Spot Price and its lag. The specifications shown in columns 3 and 4 have controls for degree days, degree days interacted with prevalence of household fuel oil use for home heating, and the unemployment rate. As with the state tax rate, these controls are obtained by taking a weighted average of the values across states within the PADD. Each independent variable has been first-differenced. 
Table 4: Incidence of Gasoline Taxes on Prices

\begin{tabular}{|c|c|c|c|c|}
\hline & $(1)$ & $(2)$ & $(3)$ & $(4)$ \\
\hline State gas tax & $\begin{array}{l}1.066 \\
(0.089) * * *\end{array}$ & $\begin{array}{l}1.069 \\
(0.088) * * *\end{array}$ & $\begin{array}{l}1.053 \\
(0.054) * * *\end{array}$ & $\begin{array}{l}1.054 \\
(0.054) * * *\end{array}$ \\
\hline Federal gas tax & $\begin{array}{l}1.034 \\
(0.192) * * *\end{array}$ & $\begin{array}{l}1.038 \\
(0.190)\end{array}$ *** & & \\
\hline State tax $\mathrm{t}-1$ & & & & $\begin{array}{l}0.038 \\
(0.046)\end{array}$ \\
\hline WTI Crude Oil Price & $\begin{array}{l}1.125 \\
(0.146)^{* * *}\end{array}$ & $\begin{array}{l}1.125 \\
(0.145) * * *\end{array}$ & & \\
\hline WTI Price t-1 & $\begin{array}{l}1.037 \\
(0.148)\end{array}$ *** & $\begin{array}{l}1.037 \\
(0.148) * * *\end{array}$ & & \\
\hline Oct 1993 & $\begin{array}{l}2.705 \\
(1.186)^{* *}\end{array}$ & $\begin{array}{l}2.688 \\
(1.175) * *\end{array}$ & & \\
\hline Minimum neighbor tax & & $\begin{array}{l}-0.302 \\
(0.162)^{*}\end{array}$ & $\begin{array}{c}-0.029 \\
(0.124)\end{array}$ & $\begin{array}{c}-0.030 \\
(0.124)\end{array}$ \\
\hline Unemployment rate & & $\begin{array}{l}-0.271 \\
(0.727)\end{array}$ & $\begin{array}{l}0.011 \\
(0.246)\end{array}$ & $\begin{array}{l}0.016 \\
(0.248)\end{array}$ \\
\hline Year, month effects & $\mathrm{X}$ & $\mathrm{X}$ & & \\
\hline Year*month effects & & & $\mathrm{X}$ & $\mathrm{X}$ \\
\hline Observations & 10560 & 10560 & 10606 & 10560 \\
\hline R-squared & 0.47 & 0.47 & 0.77 & 0.77 \\
\hline
\end{tabular}

Standard errors clustered by year*month are in parentheses.

$*, * *, * * *$ denote significance at the $90 \%, 95 \%$, and $99 \%$ level, respectively.

The dependent variable is the one month change in the tax inclusive retail price of gasoline. Each independent variable has been first-differenced. 
Table 5: Diesel Incidence and U.S. Refinery Capacity Utilization Dependent variable: Change in tax inclusive diesel price

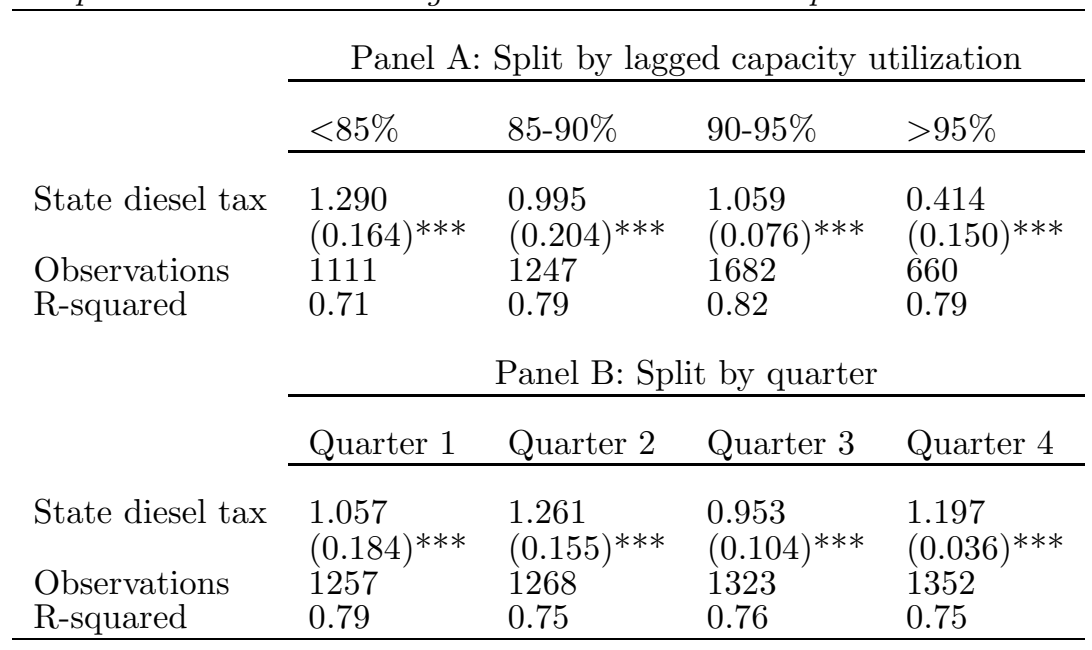

Standard errors clustered by year*month are in parentheses.

$*, * *, * * *$ denote significance at the $90 \%, 95 \%$, and $99 \%$ level, respectively.

Other controls include month*year effects, the minimum of the neighboring states' tax, the number of heating degree days, heating degree days interacted with household use fuel oil for home heating, and the state unemployment rate. Each independent variable has been first-differenced.

Table 6: Gasoline Incidence and U.S. Refinery Capacity Utilization

Dependent variable: Change in tax inclusive gas price

\begin{tabular}{|c|c|c|c|c|}
\hline \multirow{5}{*}{$\begin{array}{l}\text { State gas tax } \\
\text { Observations } \\
\text { R-squared }\end{array}$} & \multicolumn{4}{|c|}{ Panel A: Split by lagged capacity utilization } \\
\hline & $<85 \%$ & $85-90 \%$ & $90-95 \%$ & $>95 \%$ \\
\hline & $\begin{array}{l}1.036 \\
(0.115) * * * \\
1840 \\
0.84\end{array}$ & $\begin{array}{l}1.007 \\
(0.108)^{* * *} \\
2394 \\
0.82\end{array}$ & $\begin{array}{l}1.205 \\
(0.109)^{* * *} \\
3619 \\
0.77\end{array}$ & $\begin{array}{l}0.898 \\
(0.116)^{* * *} \\
1653 \\
0.65\end{array}$ \\
\hline & \multicolumn{4}{|c|}{ Panel B: Split by quarter } \\
\hline & Quarter 1 & Quarter 2 & Quarter 3 & Quarter 4 \\
\hline $\begin{array}{l}\text { State gas tax } \\
\text { Observations } \\
\text { R-squared } \\
\end{array}$ & $\begin{array}{l}1.008 \\
(0.117) * * * \\
2663 \\
0.83 \\
\end{array}$ & $\begin{array}{l}0.988 \\
(0.115)^{* * *} \\
2702 \\
0.76 \\
\end{array}$ & $\begin{array}{l}1.065 \\
(0.077)^{* * *} \\
2620 \\
0.71 \\
\end{array}$ & $\begin{array}{l}1.394 \\
(0.048) * * * \\
2621 \\
0.73 \\
\end{array}$ \\
\hline
\end{tabular}

Standard errors clustered by year*month level are in parentheses. $*, * *, * * *$ denote significance at the $90 \%, 95 \%$, and $99 \%$ level, respectively.

Other controls include month*year effects, the minimum of the neighboring states' tax, and the state unemployment rate. 
Table 7: Fuel Tax Incidence and Fuel Inventories

Dependent variable: Change in tax inclusive fuel price

\begin{tabular}{|c|c|c|c|c|c|c|c|c|c|}
\hline & & \multicolumn{4}{|c|}{ Panel A: Diesel } & \multicolumn{4}{|c|}{ Panel B: Gasoline } \\
\hline & & $(1)$ & $(2)$ & $(3)$ & $(4)$ & $(5)$ & $(6)$ & $(7)$ & $(8)$ \\
\hline & State fuel tax & $\begin{array}{l}1.092 \\
(0.081) * * *\end{array}$ & $\begin{array}{l}1.082 \\
(0.137) * * *\end{array}$ & $\begin{array}{l}1.042 \\
(0.141) * * *\end{array}$ & $\begin{array}{l}1.013 \\
(0.133) * * *\end{array}$ & $\begin{array}{l}1.051 \\
(0.056) * * *\end{array}$ & $\begin{array}{l}0.636 \\
(0.155) * * *\end{array}$ & $\begin{array}{l}0.565 \\
(0.170) * * *\end{array}$ & $\begin{array}{l}0.565 \\
(0.172)^{* * *}\end{array}$ \\
\hline & Inventories & -0.045 & -0.048 & -0.048 & -0.006 & 0.096 & -0.057 & -0.099 & -0.090 \\
\hline & & $(0.020)^{* *}$ & $(0.039)$ & $(0.040)$ & $(0.037)$ & $(0.039)^{* *}$ & $(0.031)^{*}$ & $(0.043)^{* *}$ & $(0.045)^{* *}$ \\
\hline & Lagged inventories & & & & $\begin{array}{l}-0.112 \\
(0.021) * * *\end{array}$ & & & & $\begin{array}{l}-0.224 \\
(0.045) * * *\end{array}$ \\
\hline & State tax $*$ Inventories & & 0.000 & 0.000 & 0.001 & & 0.009 & 0.012 & 0.012 \\
\hline & & & $(0.002)$ & $(0.002)$ & $(0.002)$ & & $(0.003) * * *$ & $(0.004)^{* * *}$ & $(0.004)^{* * *}$ \\
\hline \multirow[t]{10}{*}{$\stackrel{0}{\oplus}$} & State tax $*$ Bottom $10 \%$ Inventories & & & 0.594 & 0.564 & & & 0.194 & 0.177 \\
\hline & & & & $(0.297)^{* *}$ & $(0.320)^{*}$ & & & $(0.243)$ & $(0.225)$ \\
\hline & Bottom $10 \%$ Inventories & & & 0.021 & -0.056 & & & 0.139 & 0.000 \\
\hline & & & & $(0.354)$ & $(0.352)$ & & & $(0.527)$ & $(0.498)$ \\
\hline & State tax $*$ Top $10 \%$ Inventories & & & 0.126 & 0.106 & & & -0.330 & -0.382 \\
\hline & & & & $(0.259)$ & $(0.258)$ & & & $(0.192)^{*}$ & $(0.194)^{* *}$ \\
\hline & Top $10 \%$ Inventories & & & -0.422 & -0.056 & & & -0.083 & -0.067 \\
\hline & & & & $(0.355)$ & $(0.366)$ & & & $(0.074)$ & $(0.096)$ \\
\hline & Observations & 5114 & 5114 & 5114 & 5029 & 10606 & 10606 & 10606 & 10560 \\
\hline & R-squared & 0.77 & 0.77 & 0.78 & 0.78 & 0.78 & 0.78 & 0.78 & 0.78 \\
\hline
\end{tabular}

Standard errors clustered by year*month are in parentheses.

$*, * *, * * *$ denote significance at the $90 \%, 95 \%$, and $99 \%$ level, respectively.

Inventories are measured as days of supply, where supply is a moving average of quantities sold in the prior 12 months. The variable bottom $10 \%$ inventories is an indicator for the level of the days supply measure for that month being in the bottom ten percent of months in the sample. The variable "top 10\% inventories" is similarly defined. All variables have been first-differenced. Other controls for both diesel and gasoline include month*year effects, the minimum of the neighboring states' tax, and the state unemployment rate. In addition, for the diesel regressions, we include the number of heating degree days, fuel oil for home heating, and heating degree days interacted with household use. 
Table 8: Gasoline Content Regulations and Tax Incidence Dependent variable: Change in tax inclusive gasoline retail price

\begin{tabular}{llll}
\hline & $(1)$ & $(2)$ & $(3)$ \\
\hline State gas tax & $1.062^{* * *}$ & $1.063^{* * *}$ & $0.639^{* *}$ \\
& $(0.0596)$ & $(0.0597)$ & $(0.239)$ \\
Percent Reformulated Gas & & 1.643 & $2.230^{* *}$ \\
& & $(1.131)$ & $(1.062)$ \\
Percent Oxygenated Gas & 0.362 & 1.520 \\
& & $(0.881)$ & $(0.960)$ \\
Sum of Squared Content Shares & & & -5.767 \\
& & & $(5.142)$ \\
Sum of Sq. Cont. Shares * & & & $0.435^{*}$ \\
State Gas Tax & 7932 & 7761 & 7761 \\
Observations & 0.785 & 0.786 & 0.786 \\
R-squared & & & $7.245)$ \\
\hline
\end{tabular}

Standard errors, clustered at the state-level, are in parentheses. $*$,**,*** denote significance at the $90 \%, 95 \%$, and $99 \%$ level, respectively. All variables have been first differenced. Other controls include month*year fixed effects, the minimum of the neighboring states' tax, and the state unemployment rate. 
Table 9: Determinants of diesel tax changes Dependent variable: Change in state diesel tax

\begin{tabular}{|c|c|c|c|}
\hline & $(1)$ & $(2)$ & $(3)$ \\
\hline Change in federal tax & $\begin{array}{l}-0.008 \\
(0.008)\end{array}$ & $\begin{array}{l}-0.010 \\
(0.008)\end{array}$ & $\begin{array}{c}-0.007 \\
(0.009)\end{array}$ \\
\hline Change in capacity utilization & $\begin{array}{l}-0.001 \\
(0.004)\end{array}$ & $\begin{array}{l}-0.003 \\
(0.005)\end{array}$ & \\
\hline Lagged change in cap. Utilization & & $\begin{array}{l}-0.007 \\
(0.005)\end{array}$ & \\
\hline Change in minimum neighbor's tax & $\begin{array}{l}-0.011 \\
(0.013)\end{array}$ & $\begin{array}{l}-0.013 \\
(0.013)\end{array}$ & \\
\hline Lagged change in minimum neighbor's tax & & $\begin{array}{l}-0.016 \\
(0.007) * *\end{array}$ & \\
\hline Change in degree days & $\begin{array}{l}0.001 \\
(0.007)\end{array}$ & $\begin{array}{l}-0.003 \\
(0.007)\end{array}$ & \\
\hline Change in degree days* $\mathrm{HH}$ fuel oil frac & $\begin{array}{l}0.014 \\
(0.016)\end{array}$ & $\begin{array}{l}0.018 \\
(0.016)\end{array}$ & \\
\hline Capacity utilization & & & $\begin{array}{c}-0.003 \\
(0.006)\end{array}$ \\
\hline Lagged capacity utilization & & & $\begin{array}{c}-0.001 \\
(0.004)\end{array}$ \\
\hline Minimum neighbor's tax & & & $\begin{array}{l}0.000 \\
(0.002)\end{array}$ \\
\hline Degree days & & & $\begin{array}{c}-0.001 \\
(0.005)\end{array}$ \\
\hline Degree days $*$ HH fuel oil frac & & & $\begin{array}{c}-0.000 \\
(0.007)\end{array}$ \\
\hline Change in unemp rate. & $\begin{array}{l}0.240 \\
(0.186)\end{array}$ & $\begin{array}{l}0.233 \\
(0.187)\end{array}$ & $\begin{array}{l}0.236 \\
(0.185)\end{array}$ \\
\hline Year, month effects & $\mathrm{X}$ & $\mathrm{X}$ & $\mathrm{X}$ \\
\hline Observations & 3300 & 3278 & 3322 \\
\hline R-squared & 0.01 & 0.01 & 0.01 \\
\hline
\end{tabular}

Standard errors, clustered at the state-level, are in parentheses.

$*, * *, * * *$ denote significance at the $90 \%, 95 \%$, and $99 \%$ level, respectively. 
Table 10: Determinants of likelihood of diesel tax increase Dependent variable: Indicator for increasing state tax rate

\begin{tabular}{|c|c|c|c|c|}
\hline & $(1)$ & $(2)$ & $(3)$ & $(4)$ \\
\hline Federal tax raised & $\begin{array}{l}-0.007 \\
(0.009)\end{array}$ & & & \\
\hline Federal tax raised last 12 months & & $\begin{array}{l}-0.009 \\
(0.005) *\end{array}$ & & \\
\hline Neighbor state's tax raised & $\begin{array}{l}0.017 \\
(0.033)\end{array}$ & & $\begin{array}{l}-0.010 \\
(0.034)\end{array}$ & \\
\hline Neighbor raised last 12 months & & $\begin{array}{l}-0.007 \\
(0.005)\end{array}$ & & $\begin{array}{l}-0.009 \\
(0.005) *\end{array}$ \\
\hline Log of lagged price & $\begin{array}{l}0.025 \\
(0.017)\end{array}$ & & $\begin{array}{l}-0.008 \\
(0.018)\end{array}$ & \\
\hline Log average price last 12 months & & $\begin{array}{l}0.025 \\
(0.016)\end{array}$ & & $\begin{array}{l}0.011 \\
(0.017)\end{array}$ \\
\hline US Refinery Capacity utilization & $\begin{array}{l}-0.001 \\
(0.001)\end{array}$ & $\begin{array}{l}-0.001 \\
(0.001)\end{array}$ & $\begin{array}{l}-0.000 \\
(0.001)\end{array}$ & $\begin{array}{l}0.000 \\
(0.001)\end{array}$ \\
\hline Lag capacity utilization & $\begin{array}{l}0.001 \\
(0.001)\end{array}$ & $\begin{array}{l}0.001 \\
(0.001)\end{array}$ & $\begin{array}{l}-0.000 \\
(0.001)\end{array}$ & $\begin{array}{l}-0.000 \\
(0.001)\end{array}$ \\
\hline Change in degree days & $\begin{array}{l}-0.003 \\
(0.002)\end{array}$ & $\begin{array}{l}-0.003 \\
(0.002)\end{array}$ & $\begin{array}{l}-0.001 \\
(0.002)\end{array}$ & $\begin{array}{l}-0.001 \\
(0.002)\end{array}$ \\
\hline Change in degree days*HH fuel oil use & $\begin{array}{l}0.007 \\
(0.003) * *\end{array}$ & $\begin{array}{l}0.007 \\
(0.003)^{* *}\end{array}$ & $\begin{array}{l}0.007 \\
(0.003)^{* *}\end{array}$ & $\begin{array}{l}0.007 \\
(0.003) * *\end{array}$ \\
\hline Change in unemp. Rate & $\begin{array}{l}0.035 \\
(0.029)\end{array}$ & $\begin{array}{l}0.038 \\
(0.029)\end{array}$ & $\begin{array}{l}0.058 \\
(0.032)^{*}\end{array}$ & $\begin{array}{l}0.057 \\
(0.031)^{*}\end{array}$ \\
\hline $\begin{array}{l}\text { Year, month effects } \\
\text { Month* vear effects }\end{array}$ & $\mathrm{X}$ & $\mathrm{X}$ & & \\
\hline Observations & 3232 & 3290 & 3232 & 3290 \\
\hline R-squared & 0.02 & 0.02 & 0.08 & 0.08 \\
\hline
\end{tabular}

Standard errors, clustered at the state-level, are in parentheses.

$*,{ }^{* *}, * * *$ denote significance at the $90 \%, 95 \%$, and $99 \%$ level, respectively.

The reported results are from a linear probability model estimated using OLS, where the dependent variable takes on a value of 1 if the state's diesel tax rate was increased in that particular month. 